\title{
Spring in the California Current: the distribution of phytoplankton species, April 1993 and April 1995
}

\author{
E. L. Venrick* \\ Marine Life Research Group, Scripps Institution of Oceanography, La Jolla, California 92093-0227, USA
}

\begin{abstract}
This study examines the distributions of 317 phytoplankton species from the survey area of the California Cooperative Oceanic Fisheries Investigations (CalCOFI). Samples were mixed-layer samples collected in April 1993 and April 1995. Both were periods of recent or active upwelling near Point Conception. There were 2 major groups of stations with similar flora, one inshore and one offshore. Effect of current flow on the boundary between the 2 regimes was evident. Stations in the southeastern portion of the area were more closely related to offshore stations in 1995; however, in 1993 there was influx of inshore flora from the north. Recurrent group procedure identified northern inshore and offshore groups of species, with similar composition in the 2 years. Northern inshore species were found throughout the CalCOFI study area, and their summed abundance was correlated with the concentration of $10 \mathrm{~m}$ chlorophyll. In 1995, no offshore group was formed unless the affinity level was relaxed. No recurrent group was endemic to the southeastern region. These diatom data were compared with diatom data of W. E. Allen, collected in April 1940. There were no marked differences in diatom abundance or species composition. However, in April 1940, an unusually well developed Southern California Eddy shifted the center of diatom abundance offshore.
\end{abstract}

KEY WORDS: Phytoplankton species - California Current Spring bloom Upwelling

\section{INTRODUCTION}

The hydrography, chemistry and biology of the southern California Current System have been extensively studied by the California Cooperative Fisheries Investigation (CalCOFI) for nearly $50 \mathrm{yr}$. These surveys, together with numerous other studies in the Southern California Bight, make this region one of the best studied areas of the ocean.

Over 50 yr ago, W. E. Allen enumerated diatoms from early cruises in the California Current (Sverdrup \& Allen 1939, Allen 1945a, b. Sargent \& Walker 1948). Since then, most studies of phytoplankton species (reviewed in Eppley 1986) have emphasized temporal rather than spatial coverage. The most extensive of these studies have been Allen's collection off the end of the piers at Point Hueneme and at Scripps Institution of Oceanography (SIO; Allen 1936, 1941, Tont 1976. 1981,1987 , Sugihara \& May 1990) and the studies con-

-E-mail: evenrick@ucsd.edu ducted by the Food Chain Research Group of SIO in the Southern California Bight (Eppley 1986 and references therein). The common denominators within and among these studies are variability and complexity. Allen (1939) described the phytoplankton off the end of the SIO pier: '. . our records show no two years alike in the twenty, no two months alike, and no two weeks alike'. Over 40 yr later, Goodman et al. (1984) wrote of the phytoplankton in the Southern California Bight: '...the sample space of phytoplankton assemblages off Southern California involves a far richer variety of assemblages than has been adequately characterized.'

Other biological characteristics in the CalCOFI area show coherent large-scale patterns (e.g. zooplankton biomass, Bernal 1979; zooplankton taxa, Colebrook 1977; chlorophyll and primary productivity, Hayward \& Venrick in press). It is possible that past phytoplankton studies have sampled the wrong scales to detect such broad patterns. On the April CalCOFI cruises in 1993 and 1995, mixed-layer phytoplankton samples were taken from each standard station. The present study presents the near-surface distributions of 317 
phytoplankton species, providing a quantitative description of 2 spring floras, their spatial patterns and their interannual differences. The synthesis of many species over a large area did, in fact, reveal cohesive spatial patterns similar to those seen in other parameters.

\section{METHODS}

Sampling and counting. The samples were collected on CalCOFI cruises 9304 (30 March to 15 April 1993) and 9504 (6 to 22 April 1995). Phytoplankton samples were enumerated from 49 stations in 1993 and 52 stations in 1995. Stations are designated by line and station number. Thus, Stn 87.70 is Stn 70 along line 87. The complete grid of 66 stations is illustrated in data reports (e.g. SIO 1993, 1995). Stations with phytoplankton samples are indicated in Figs. 3 \& 5 .

Phytoplankton samples were collected from the second standard depth, which fell within the mixed layer when a mixed layer existed. This was the only depth other than the surface that had a consistent relationship with the vertical density structure across a wide range of hydrographic conditions. Actual sample depths ranged between 3 and $22 \mathrm{~m}$ with a mean of $12.2 \mathrm{~m}$. The deeper samples were offshore, reflecting a deeper offshore mixed layer.

Phytoplankton samples were $250 \mathrm{ml}$ water samples preserved with buffered formalin to a final concentration of $1 \%$ formalin. Subsamples were diluted or were concentrated by settling and species were counted on an Utermöhl microscope. Enumerated volumes ranged from 0.17 to $100 \mathrm{ml}$. The entire sample was counted at $100 \times$ for larger species, and every sixth row was counted for smaller species. Occasionally, very small and very abundant species (Emiliania huxleyi, Gephyrocapsa spp., Fragilariopsis pseudonana and/or a small form of Nitzschia cf. bicapitata) were counted with a single transect at $400 \times$. Species identification was facilitated by transferring individual cells to an oil immersion microscope or by examining material with a scanning electron microscope.

Except when noted, all analyses were based upon taxa that could be identified to species or to a genus containing only a few species. Thus, Gephyrocapsa spp. ( 1 to 3 species) were included but 'unidentified hyalochaetes' (at least 10 species) were not. Full taxonomic nomenclature and other notes are given in Appendix 1

Grouping similar stations. The relationship between the flora of different stations was examined by calculating a nonparametric correlation coefficient (Spearman's $\rho$ ) between all pairs of stations. I have used $\rho$ as an index of similarity because it depends upon the rank order of species abundances, and therefore reflects changes in dominance of both rare and abundant species. Also, unlike many indices of similarity, it is uninfluenced by changes in underlying population distributions and it can be corrected for unequal sample sizes by referring to traditional tables of the null distributions of $\rho$. In this study, the combined list of a pair of stations varied from 20 species (Stns 93.28 and 93.35 in 1995) to 113 species (Stns 90.80 and 87.60 in 1993). In the null distribution of $\rho$ from samples of size 20 , a value of $p=0.28$ occurs more than $20 \%$ of the time by chance alone. However, in the null distribution from samples of size 113 , the same value occurs less than $0.5 \%$ of the time. Clearly, it would be misleading to use the magnitude of $\rho$ to compare these 2 pairs of stations. Instead, I referred to the standard statistical tables for the null distribution of $\rho$ to adjust for sample size. I have selected that tabulated value of $\rho$ which has a 2 -tailed $\alpha$ error of 0.01 . Two stations with a correlation equal to or greater than this value were considered to have similar flora. I examined $\alpha$ errors between 0.05 and 0.001 for consistency of outcomes. Similar patterns were obtained from all, but patterns from $\mathrm{p}=0.01$ seemed most informative.

One cannot assign a precise significance level to any single $\rho$ for 2 reasons. Since $\rho$ has been calculated for all pairs of stations, the coefficients are not independent, and this violates 1 assumption of hypothesis testing. Also, the large number of correlations means that some will be large by chance alone (the problem of multiple testing). I am using $\rho$ as a qualitative index of similarity, much like the percent similarity index is used. In spite of the reference to statistical tables to correct for sample size, I do not imply significance in the probabilistic sense.

The spatial relationships among stations were visualized by connecting each pair of similar stations ( $p \leq$ 0.01 ) with a straight line. This method was used when the nature of the underlying data precluded more conventional techniques (Abbott \& Zion 1987). I used it because it presents relationships directly in the dimensions of interest, the grid of CalCOFI stations, and thus is sensitive to influences of hydrography on floristic distributions.

A few stations had no similarities at $p \leq 0.01$. These stations were associated with others on the basis of the maximum positive correlation with another station.

Although the groups of stations were subjective, their statistical significance could be determined by examining the distributions of dissimilarities (negative correlations at $p \leq 0.01$ ) and neutral relationships ( $p>0.01$ ) within and among groups against the null hypothesis that their distributions were random. This was done with a modified $\chi^{2}$ statistic. Since station groups were defined on the basis of their similarities, 
only negative and neutral relationships were used in the calculation of $\chi^{2}$, eliminating logical circularity. Because of the dependencies in the data set and the modifications to the calculated $\chi^{2}$, randomization methods (Manly 1991) were used to develop the null distribution of this $\chi^{2}$ statistic. Stations were randomly assigned to groups, the distributions of negative and neutral correlations within and among groups were determined and the resulting $\chi^{2}$ statistic was calculated. Each null distribution was based upon 500 simulations.

Grouping similar species. To examine species with similar distribution patterns, I used recurrent group analysis (Fager 1957, Fager \& McGowan 1963). This utilizes a coefficient of affinity, $\alpha$, calculated between all pairs of species. Species are formed into groups within which all species pairs have an affinity index greater than a specified value. Associated species are those that have positive affinities with some but not all members of a group. In the original procedure, $\alpha$ was based upon scores of presence and absence, and a high $\alpha$ indicated 2 species which tended to co-occur. I have based $\alpha$ on scores $\geq$ the median abundance and < the median abundance; in this case a high $\alpha$ indicates 2 species which tended to be abundant in the same sample. In the case of species present in less than half of the samples, scores above/below the medians are identical to scores of presence/absence.

I initially ran the recurrent group analysis at 4 levels of $\alpha$ : 0.90 (no groups were formed), $0.80,0.70$, and 0.60 . At higher values a few small groups of closely related and very abundant species were formed. As the affinity was lowered, groups became larger, the relationships between species within a group became weaker and the spatial cohesiveness of the group diminished; also, more seemingly fallacious groupings appeared, especially as species pairs. These are typical patterns of outcome for the recurrent group procedure. Scanning across several levels of $\alpha$ is a useful means of evaluating the consistency of relationships between species and between groups. In the present analysis most of the information was contributed by the groups of 3 or more species formed at $\alpha=0.70$. Unless otherwise noted, these groups have been used as the basis for interpretation.

Comparison with the Allen data. W. E. Allen counted diatoms from water samples collected at $10 \mathrm{~m}$ intervals between the surface and $60 \mathrm{~m}$ depth. The water was filtered through no. 25 bolting cloth to concentrate the cells, which were subsequently counted in SedgwickRafter chambers (Allen 1941). The nominal mesh size of the net was about $65 \mu \mathrm{m}$. However, the captured diatoms themselves reduce mesh size, increasing retention, especially in areas of high concentration (Tangen 1978). To facilitate comparison between Allen's data and my own. I removed from my data the counts of 4 very small pennate diatoms that were unlikely to be adequately retained by Allen's procedure (Fragilariopsis pseudonana, small forms of Nitzschia cf. bicapitata and of cf. Nitzschia sicula and 'epiphytic cylinder'). I also added all unidentified diatoms to my totals

Other statistical procedures. Other statistical procedures were standard nonparametric procedures found in most text books (e.g. Conover 1971, Zar 1984). Derived statistics included the coefficient of variation (standard deviation/mean) and Pielou's index of evenness (Legendre \& Legendre 1983).

\section{RESULTS}

\section{Environmental setting}

In the present CalCOFI study area, March to May is the season in which phytoplankton biomass (chlorophyll) and productivity typically reach their annual maximum. This occurs in response to the shoaling of the nutricline in the vicinity of Point Conception (Sverdrup \& Allen 1939, Jones et al. 1983, Hayward \& Venrick in press). During 1992 and 1993, the California Current was under the influence of an El NiñoSouthern Oscillation (ENSO) event. This was characterized by an elevation of sea level, a warming of nearsurface temperatures and a reduction in chlorophyll concentrations throughout the region (Hayward et al, 1994). In April of both 1992 and 1993, however, there was a relaxation of the strength of the ENSO. As more normal circulation patterns resumed, characteristic spring blooms developed.

Conditions in April 1993 indicated active upwelling and enrichment of the northern portion of the study region (Fig. 1A). Southward flow was strong and meandering. At Stns 77.49 and 80.51, near-surface low temperatures (10.2 and $10.7^{\circ} \mathrm{C}$, respectively), high nitrate (20 and $19 \mu \mathrm{M} \mathrm{l}^{-1}$, respectively) and oxygen undersaturation (69 and 65\%, respectively) were characteristic of recent upwelling, as was the locally reduced chlorophyll at Stn 80.51 (Barber \& Smith 1981, Jones et al. 1983). Nutrients decreased and chlorophyl and oxygen saturation increased to the south and west. High inshore chlorophyll values along line 77 may have indicated advection into the study region from the north. The total chlorophyll, integrated through the water column and averaged over the study region, was the second highest spring total since routine measurements began in 1984 (Hayward et al. 1994). Thus, the data from April 1993 indicated typical spring conditions in the California Current, even though the month was embedded in an ENSO period. 
A
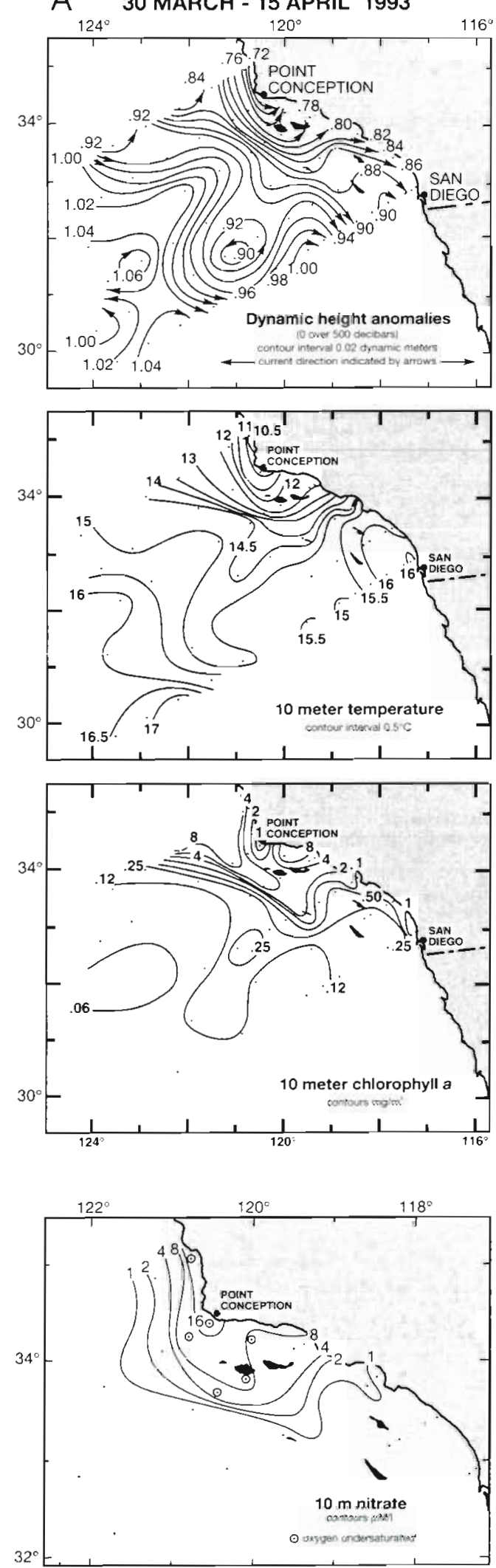
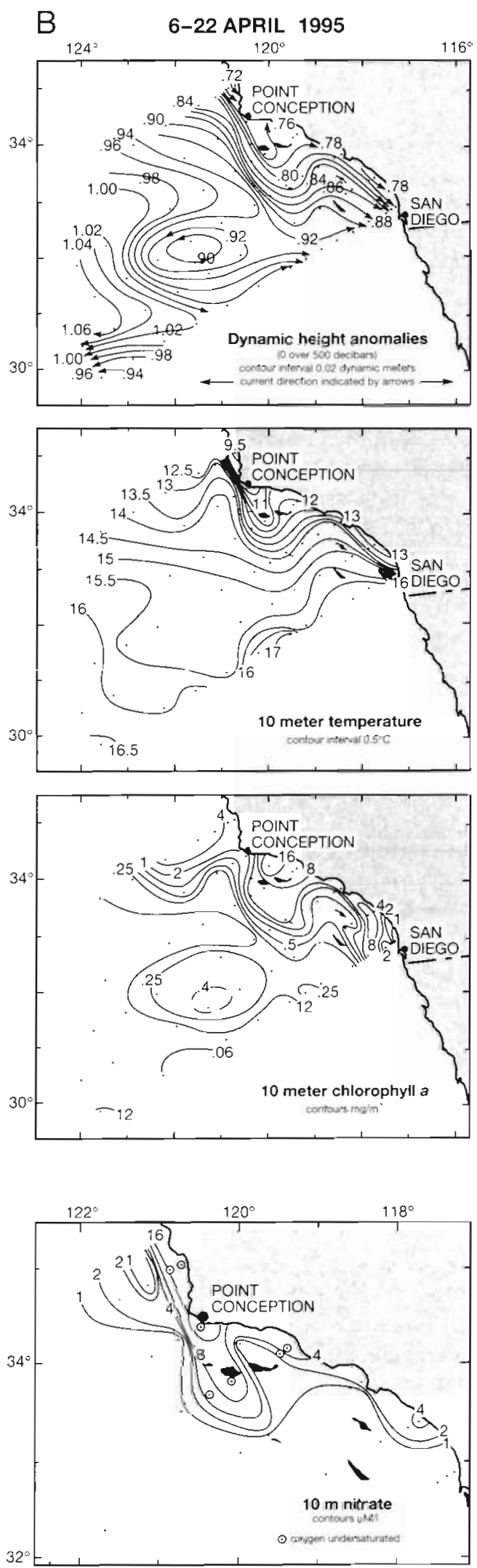

Fig. 1. Dynamic height anomalies and environmental characteristics at $10 \mathrm{~m}$ for (A) 30 March to 15 April 1993 and (B) 6 to 22 April 1995 
The maps of dynamic height show an offshore cyclonic eddy centered near Stn 90.80. Isolines of density and nutrients domed at the eddy center. A local near-surface chlorophyll maximum at Stn 87.70 was offset from the eddy center and was presumably associated with it.

Environmental conditions during April 1995 were similar to those in 1993 (Fig 1B). Cool temperatures, elevated nitrate values, undersaturated oxygen and reduced chlorophyll concentrations in near-surface waters indicated recent upwelling near Stns 77.49, 77.51 and 80.51. An offshore cyclonic eddy was centered near Stn 87.80. A local $10 \mathrm{~m}$ chlorophyll maximum appeared at Stn 90.80 , again offset from the eddy center. Total chlorophyll for the cruise was slightly greater than in 1993 (Hayward et al. 1996).

In January-March 1995 a massive bloom of Gonyaulax polyedra (now Lingulodinium polyedra) was recorded near the coast from San Diego to Santa Barbara. (Hayward et al. 1995). At La Jolla, concentrations exceeded 200000 cells per $100 \mathrm{ml}$ with maximum chlorophyll concentrations between 150 and $500 \mathrm{mg}$ $\mathrm{m}^{-3}$. Toward the end of the bloom, visible aggregations of Noctiluca scintillans were evident offshore of $\mathrm{La}$ Jolla. Although the bloom had largely dissipated in the coastal area by April, higher than normal abundances of both $G$. polyedra and $N$. scintillans were found throughout all but the northernmost portions of the CalCOFI station pattern (Fig. 2). The maximum abundance of $G$. polyedra was 2000 cells per $100 \mathrm{ml}$ at Stn 93.35. For comparison, in 1993 cells occurred sporadically and usually singly, and the maximum abundance was 41 cells per $100 \mathrm{ml}$ at Stn 93.27.

Details of conditions during CalCOFI cruises 9304 and 9504 are discussed more fully elsewhere (Hay-

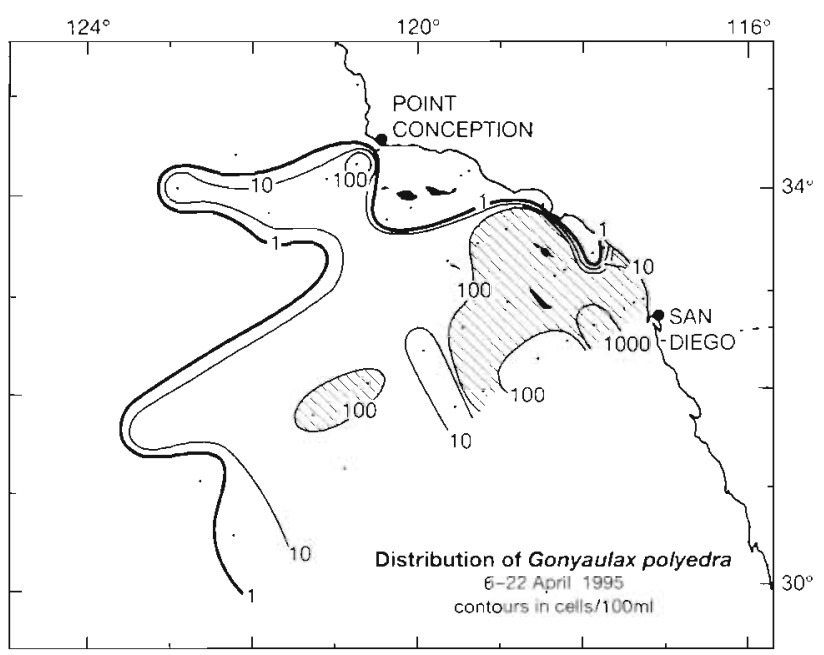

Fig. 2. Gonyaulax polyedra. Distribution and abundance in the mixed layer, 6 to 22 April 1995. Shading indicates abundances in excess of 100 cells per $100 \mathrm{ml}$ ward et al. 1994, 1995, 1996). Additional physical, chemical and biological data may be found in the CalCOFI data reports (SIO 1993, 1995).

\section{Station groups}

The floristic relationships between stations in 1993, based upon Spearman's nonparametric correlation coefficient $(p)$, are shown in Fig. 3. For clarity, the relationships of Stn 87.70 have been plotted separately (Fig. 3B). This was the station with a local maximum of $10 \mathrm{~m}$ chlorophyll associated with the offshore eddy. The species at this station were clearly derived from northern nearshore flora. This is a striking example of offshore transport, although the data do not allow us to differentiate between near-surface transport of shallow populations and shoaling of deeper cells.
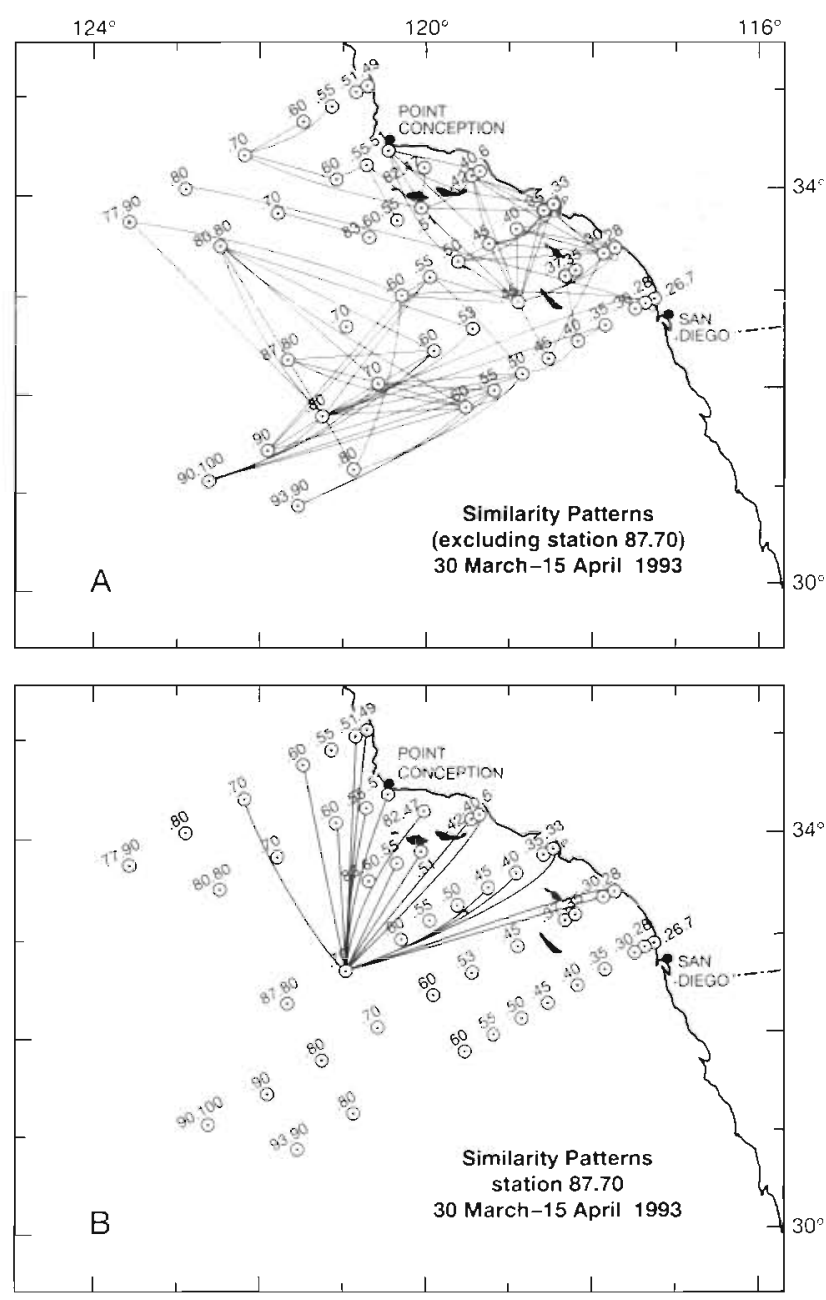

Fig. 3. Similarities between stations, 30 March to 15 April 1993. Two stations are connected by a line when the rank orders of species abundances have a correlation which exceeds the critical value at $p \leq 0.01$ (A) All stations except Stn 87.70. (B) Similanties involving station 87.70 
Two major groups of stations were apparent, one located inshore along line 90 and north, including Stn 87.70 , and the other located offshore. Nearshore stations had a similar flora that was distinct from the flora of offshore stations. The outer boundary of this group of stations corresponded roughly to the chlorophyll contour of $0.25 \mathrm{mg} \mathrm{m}^{-3}$ (Fig. 1A). Thus, the northern inshore stations were influenced by the enrichment occurring near Point Conception. In contrast, offshore stations were characterized by low nutrients and low near-surface chlorophyll.

Some stations along line 93 from the coast to Stn 93.45 were floristically similar to offshore stations (Stns 93.35 and 93.28), others to inshore stations (Stns 93.40 and 93.45). This suggests a region of confluence where inshore species were brought south by the California Current and offshore species were brought east by the onshore flow of water that is typical of this latitude (Pelaez \& McGowan 1986. Thomas \& Strub 1990). This onshore transport is suggested by the map of dynamic height (Fig. 1A), but the major eastward flow at this time was south of the CalCOFI region. There were very few simularities among this southeastern group of stations. These stations were examined as an independent group, but the existence of a distinct flora here was not established. Stn 90.35 had no similarities with either inshore or offshore stations and was grouped with the northern inshore stations on the basis of the strongest positive correlation. The exact grouping of stations used in the following analyses is indicated in Fig. 4.

If the groups apparent in Fig. 3 are meaningful, there should have been not only more similarities within a group than between groups, but also more dissimilarities between groups than within. The distributions of the number of similar and dissimilar correlations ( $p \leq$ $0.01)$ and neutral relationships $(p>0.01)$ within and between each of the 3 regions are given in Table 1 , along with the numbers expected if the distributions of relationships were independent of the groups (i.e. random). Clearly the similarities tended to occur between stations of the same group, and the dissimilarities tended to occur between stations of different groups. However, in the southeastern region, stations had fewer large correlations than expected, either positive or negative, consistent with the hypothesis of incomplete mixing of floras. Because the groups were defined on the basis of their similarities, only the frequencies of neutral and negative relationships were examined statistically. Over the entire data set, the distribution was significantly different from that expected if, in fact, the station groupings had no meaning (randomization $\chi^{2}, p<0.002$ ). The largest components of the $\chi^{2}$ were the large numbers of dissimilarities between northern inshore and offshore stations and the low number of dissimilarities within these 2 groups.
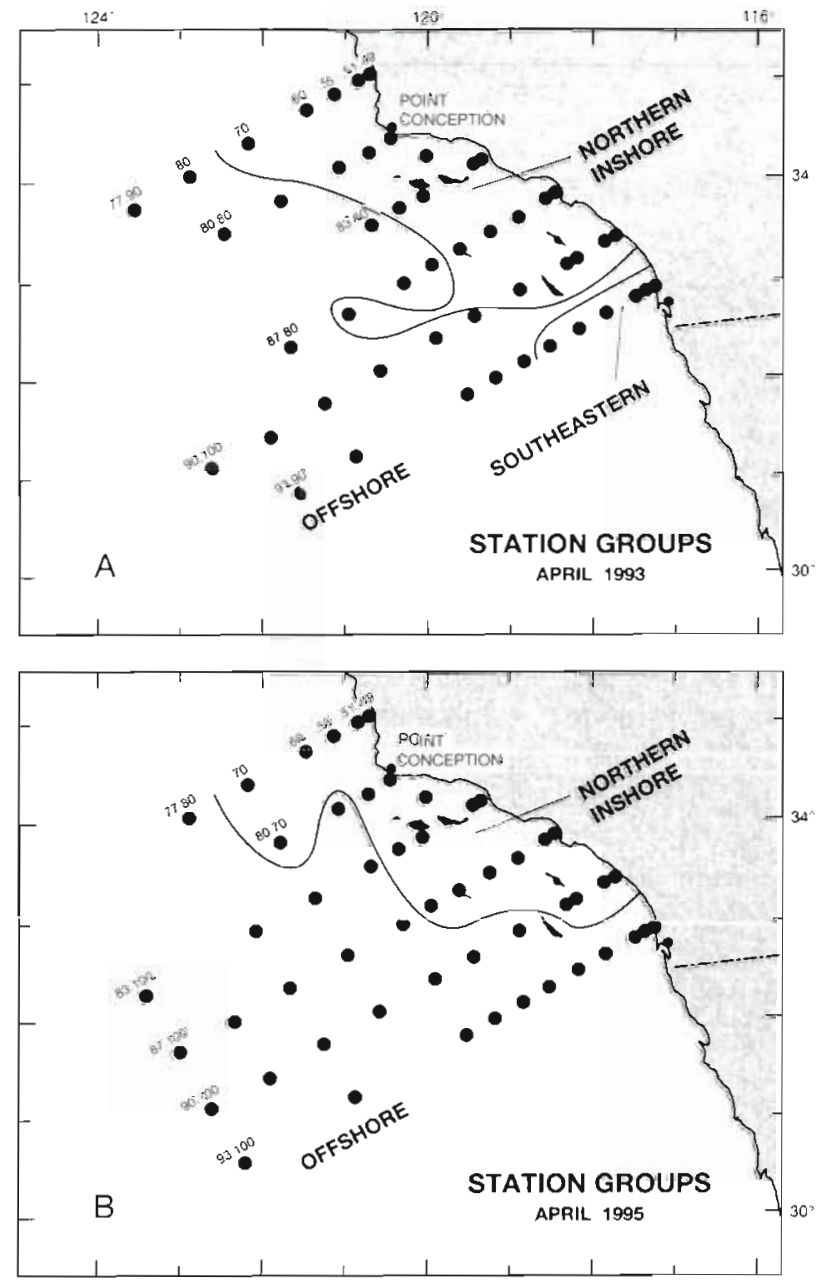

Fig. 4. Composition of station groups used in subsequent analyses. (A) Northern and southern inshore and offshore groups, 30 March to 15 April 1993. (B) Inshore and offshore groups, 6 to 22 April 1995

I have pooled the data within each group to obtain a general description of the flora (Table 2). There were 162 species present in the northern inshore region. The top 10 included 9 diatoms and a coccolithophore. The offshore region included 190 species dominated by 4 diatoms, 3 coccolithophores, the colonial form of Phaeocystis, a photosynthetic dinoflagellate and a phagotrophic cryptomonad. Four of the nearshore dominants were also dominants of the offshore region, although their abundances were reduced offshore.

The species that dominated the southeast region included a mixture of species from the other 2 regions and the dinoflagellate Gymnodinium sanguineum, which is a frequent component of nearshore red tides.

When these analyses were repeated using the 1995 data, a nearshore group of stations again emerged (Fig. 5). It was centered somewhat farther north than 
Table 1. Distribution of similar and dissimilar $(p<0.01)$ and neutral relationships $(p>0.01)$ within and between station groups (inshore, offshore, and southeastern, SE). Values are the observed frequencies (Obs.) and those expected under the null hypothesis of random distribution of relationships (Exp.). Expected values in parentheses were recalculated from the distribution of negative and neutral relationships only. The $\chi^{2}$ statistic was calculated from expected values in parentheses

\begin{tabular}{|c|c|c|c|c|c|c|}
\hline \multirow{2}{*}{ Comparison } & \multicolumn{2}{|c|}{ Similar } & \multicolumn{2}{|c|}{ Dissimilar } & \multicolumn{2}{|c|}{ Neutral } \\
\hline & Obs. & Exp. & Obs. & Exp. & Obs. & Exp. \\
\hline \multicolumn{7}{|l|}{1993} \\
\hline Inshore-inshore & 58 & 26.5 & 16 & $51.2(44.7)$ & 202 & $198.3(173.3)$ \\
\hline Oftshore-offshore & 41 & 16.4 & 0 & $31.7(26.7)$ & 130 & $122.9(103.3)$ \\
\hline SE-SE & 2 & 1.4 & 0 & $2.8(2.7)$ & 13 & $10.8(10.3)$ \\
\hline Inshore-offshore & 2 & 43.8 & 172 & $84.5(93.1)$ & 282 & $327.7(360.9)$ \\
\hline Inshore-SE & 5 & 13.8 & 19 & $26.7(28.5)$ & 120 & $103.5(110.5)$ \\
\hline Offshore-SE & 5 & 11.0 & \multicolumn{2}{|c|}{$\chi^{2}=155.4$} & \multicolumn{2}{|c|}{$(p<0.002)$} \\
\hline 1995 & & & & & & \\
\hline Inshore-inshore & 42 & 6.4 & 0 & $41.9(32.9)$ & 129 & $122.6(96.1)$ \\
\hline Offshore-offshore & 8 & 19.9 & 64 & $129.4(132.4)$ & 456 & $378.7(387.6)$ \\
\hline Inshore-offshore & 0 & 23.6 & \multicolumn{2}{|c|}{$\chi^{2}=177.8$} & \multicolumn{2}{|c|}{$\begin{array}{l}366 \quad 449.7(467.3) \\
(0<0.002)\end{array}$} \\
\hline
\end{tabular}

siveness seen in 1993. Unlike 1993, all stations inshore along line 93 tended to be most similar to the offshore stations.

The major discrepancies between the observed and expected frequencies of similar and dissimilar relationships were the large number of similarities and lack of dissimilarities among inshore stations, the large number of dissimilarities between inshore and offshore stations, and the low number of dissimilarities among offshore stations (Table 1 ). A $\chi^{2}$ value based upon only neutral and negative relationships was significant ( $\mathrm{p}<$ 0.002). Thus, in spite of the reduced cohesiveness among offshore stations, they were clearly different from the northern inshore stations and had fewer internal dissimilarities than would be expected were they merely random collections of stations.

Pooling data from the inshore stations gave a total of 142 species. The mean species structure was dominated by 9 diatoms and a coccolithophore (Table 3 ). All but 2 of these species were also dominant at the northern inshore stations in 1993. In contrast, only 4 of the 10 dominant offshore species in 1995 were also dominant in 1993 (Tables 2 \& 3). The most striking difference was Gonyaulax polyedra, which ranked 4th in 1995 (133 cells per $100 \mathrm{ml}$ ) and 139.5th in 1993 ( 0.5 cells per $100 \mathrm{ml}$ ). This was clearly a residual of the massive red tide seen earlier in the year. Peridinium cf. steinii, a nonphotosynthetic dinoflagellate which ranked 8 th in 1995, may also have been related to the red tide. A pennate diatom that ranked 52nd in 1993 was 10th in 1995. Reranking among other species was minor

The dichotomy between inshore and offshore flora was also apparent over time. To examine this, Spearman's $\rho$ was calculated between each pair of stations, one from 1993 and one from 1995 (Fig. 6). Of the 46 stations sampled in both years, only 2 stations $(83.55$ and 70.80) had a flora in 1993 that was similar to its own flora in 1995. The relative frequency of similar station pairs between the 2 years $(2.2 \%)$ was lower than the relative frequency in the same year $(9.6 \%$ in 1993 and $3.7 \%$ in 1995), but the distribution of negative and neutral relationships between and within inshore and offshore stations was significant (Table 4). Thus, the spring flora of the inshore stations was temporally persistent or recurrent, at least over the 2 years of this study. The offshore stations had more positive similarities between years than within in 1995, suggesting that the same floral elements were tions, but the offshore region clearly lacked the cohe- 
Table 2. Floral composition of the 3 regions in the CalCOFl area, in April 1993. Values are the regional mean abundances of the 10 dominant species and other species mentioned in text. Also given are the numbers of species per region out of a total list of 240

\begin{tabular}{|c|c|c|}
\hline Species & $\begin{array}{l}\text { Mean } \\
\text { cells per } 100 \mathrm{ml}\end{array}$ & Rank \\
\hline \multicolumn{3}{|l|}{ Inshore stations } \\
\hline Chaetoceros debilis & 20048 & 1 \\
\hline Skeletonema costatum & 18056 & 2 \\
\hline Pseudo-nitzschia spp. (delicate forms) & 10307 & 3 \\
\hline Chaetoceros radicans & 7363 & 4 \\
\hline Emiliania huxleyi & 4604 & 5 \\
\hline 'Epiphytic cylinder' & 3690 & 6 \\
\hline Fragilariopsis pseudonana & 3399 & 7 \\
\hline Chaetoceros costatus & 2780 & 8 \\
\hline Pseudo-nitzschia spp. (robust forms) & 1476 & 9 \\
\hline Chaetoceros compressus & 1403 & 10 \\
\hline Chaetoceros socialis & 1103 & 11 \\
\hline Cylindrotheca closterium & 1034 & 13 \\
\hline Chaetoceros didymus & 1032 & 14 \\
\hline Thalassionema nitzschioides & 601 & 18 \\
\hline Leptocylindrus cf danicus & 481 & 20 \\
\hline \multicolumn{3}{|l|}{ Total number of species: 162} \\
\hline \multicolumn{3}{|l|}{ Offshore stations } \\
\hline Emiliania huxleyi & 1296 & 1 \\
\hline Gephyrocapsa spp. & 765 & 2 \\
\hline Nitzschia bicapitata (small form) & 314 & 3 \\
\hline Fragilariopsis pseudonana & 260 & 4 \\
\hline Pseudo-nitzschia spp. (delicate forms) & 186 & 5 \\
\hline Phaeocystis pouchetii & 149 & 6 \\
\hline Skeletonema costatum & 110 & 7 \\
\hline Leucocryptos marina & 95 & 8 \\
\hline Gephyrocapsa ornata & 86 & 9 \\
\hline Oxytoxum variabile & 77 & 10 \\
\hline Cylindrotheca closterium & 63 & 11 \\
\hline Helicosphaera carteri & 59 & 12 \\
\hline Mastogloia woodiana & 40 & 13 \\
\hline Glenodinium spp. & 38 & 14 \\
\hline Syracosphaera pulchra & 8.7 & 32 \\
\hline Torodinium spp. & 3.8 & 48 \\
\hline Haslea wawrikae & 3.5 & 52 \\
\hline Peridinium cf steinii & 1.1 & 77 \\
\hline Gonyaulax polyedra & 0.5 & 139.5 \\
\hline \multicolumn{3}{|l|}{ Total number of species: 190} \\
\hline \multicolumn{3}{|l|}{ Southeast stations } \\
\hline Fragilariopsis pseudonana & 2631 & 1 \\
\hline Gephyrocapsa spp. & 1.601 & 2 \\
\hline Emiliania huxleyi & 1379 & 3 \\
\hline Phaeocystis pouchetii & 407 & 4 \\
\hline Pseudo-nitzschia spp. (delicate forms) & 356 & 5 \\
\hline Cylindrotheca closterium & 318 & 6 \\
\hline Leucocryptos marina & 177 & 7 \\
\hline Nitzschia cf. longissima & 144 & 8 \\
\hline Nitzschia bicapitata (small form) & 122 & 9 \\
\hline Gymnodinium sanguineum & 109 & 10 \\
\hline Total number of species: 117 & & \\
\hline
\end{tabular}

present during the 2 years but that species were more heterogeneous in 1995. It is not surprising that the southeastern region, which had low cohesiveness within years, did not appear to have a temporally persistent flora.
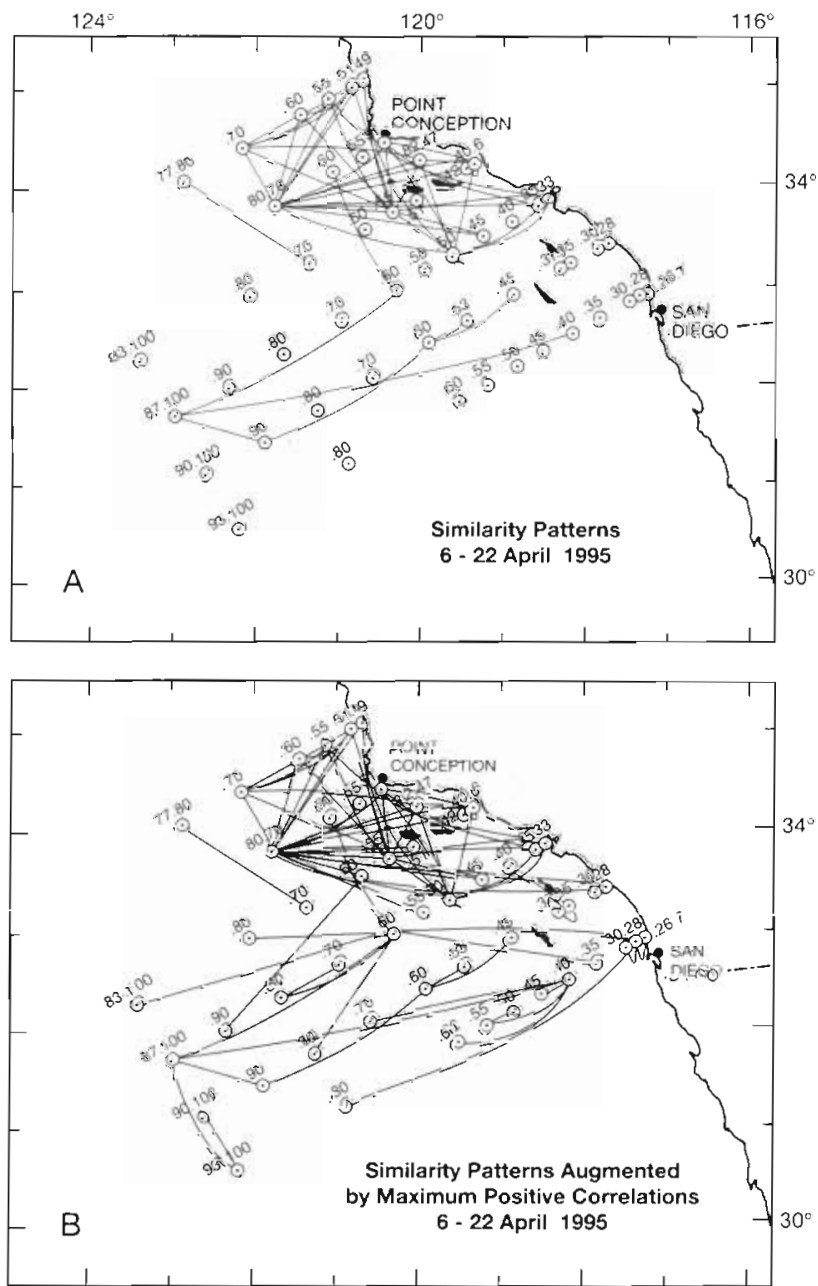

Fig. 5. Similarities between stations, 6 to 22 April 1995. (A) Stations are connected by a line when the rank orders of species abundances have a correlation which exceeds the critical value at $p \leq 0.01$ (B) Same as (A) but each station without similarities has been connected to the station with which it has the maximum positive correlation

An unexpected result of this analysis is the fact that the similarities seemed to be concentrated at 4 stations. Of the 40 interannual similarities within the inshore region, 12 involved Stn 87.70 in 1993 (the eddy station), 12 involved Stn 80.70 in 1995 (the meander station), and 9 involved $\operatorname{Stn} 77.55$ in 1995. Offshore, there were 13 internal similarities of which 8 involved Stn 90.80 in 1993. There is no immediate explanation for this pattern.

\section{Species groups}

In 1993, the largest recurrent group at $\alpha=0.70$ contained 6 diatoms with 3 associated diatoms (Table 5). All 9 were abundant at the inshore stations (Table 2). 
Table 3. Floral composition of 2 regions in the CalCOFI area, in April 1995. Values are the regional mean abundances of the 10 dominant species and other species mentioned in text. Also given are the numbers of species per region out of a total list of 247

\begin{tabular}{|c|c|c|}
\hline Species & $\begin{array}{l}\text { Mean } \\
\text { cells per } 100 \mathrm{mll}\end{array}$ & Rank \\
\hline \multicolumn{3}{|l|}{ Inshore stations } \\
\hline Chaetoceros socialis & 59317 & 1 \\
\hline Chaetoceros debilis & 14833 & 2 \\
\hline Skeletonema costatum & 8232 & 3 \\
\hline Chaetoceros radicans & 3893 & 4 \\
\hline Pseudo-nitzschia spp. (delicate forms) & 3334 & 5 \\
\hline Emiliania huxleyi & 3096 & 6 \\
\hline 'Epiphytic cylinder' & 3074 & 7 \\
\hline Chaetoceros cf. vanheurcki & 2665 & 8 \\
\hline Pseudo-nitzschia spp. (robust forms) & 2294 & 9 \\
\hline Chaetoceros compressus & 2100 & 10 \\
\hline Leptocylindrus cf. danicus & 1866 & 11 \\
\hline Chaetoceros didymus & 1651 & 12 \\
\hline Cylindrotheca closterium & 1169 & 13 \\
\hline Chaetoceros costatus & 704 & 18 \\
\hline Fragilariopsis pseudonana & 356 & 26 \\
\hline Thalassionema nitzschioides & 289 & 29 \\
\hline Gonyaulax polyedra & 149 & 36 \\
\hline \multicolumn{3}{|l|}{ Total number of species: 142} \\
\hline \multicolumn{3}{|l|}{ Offshore stations } \\
\hline Emiliania huxleyi & 228 & 1 \\
\hline Gephyrocapsa spp. & 189 & 2 \\
\hline Fragilariopsis pseudorana & 180 & 3 \\
\hline Gonyaulax polyedra & 133 & 4 \\
\hline Cylindrotheca closterium & 96 & 5 \\
\hline Pseudo-nitzschia spp. (delicate forms) & 86 & 6 \\
\hline Mastogloia woodiana & 57 & 7 \\
\hline Peridinium cf. steinii & 44 & 8 \\
\hline Glenodinium spp. & 40 & 9 \\
\hline Haslea wawrikae & 39 & 10 \\
\hline Syracosphaera pulchra & 35 & 11 \\
\hline Nitzschia cf. bicapitata (small form) & 33 & 12 \\
\hline Phaeocystis pouchetii & 33 & 13 \\
\hline Leucocryptos marina & 28 & 15 \\
\hline Oxytoxum variabile & 27 & 17 \\
\hline Dictyocha fibula & 12 & 25 \\
\hline Helicosphaera carteri & 5.1 & 36 \\
\hline Torodinium spp. & 1.6 & 73 \\
\hline Skeletonema costatum & 0.7 & 99 \\
\hline Total number of species: 208 & & \\
\hline
\end{tabular}

The sum of the abundances of the 6 species was highly correlated with the distribution of $10 \mathrm{~m}$ chlorophyll $(p=0.91, p<0.001$; Fig. 7A). The group was most abundant in the region around Point Conception and had local minima at newly enriched Stns 77.49 and 80.51 Some species were present at all stations except Stn 93.90, in the extreme southwest corner of the region. Their offshore transport in the meander and cyclonic eddy was evident. On average, these 6 species accounted for $24 \%$ ( 0 to $84 \%$ ) of the phytoplankton cells. The close relationship with chlorophyll indicates that they represented a larger set of species with similar distribution patterns.

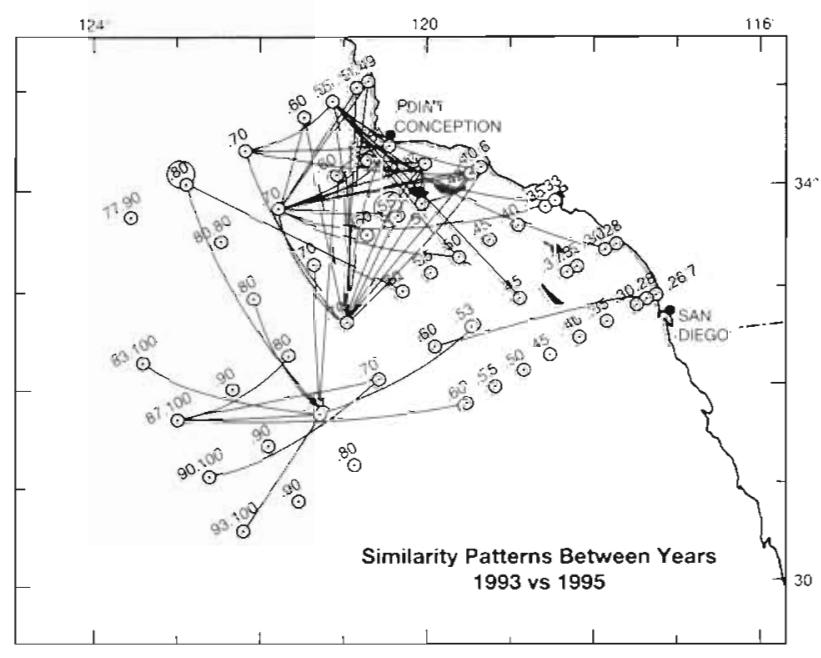

Fig. 6. Similarities between stations, April 1993 and April 1995. Two stations, one from each year, are connected by a line when the rank orders of species abundances have a correlation which exceeds the critical value at $p \leq 0.01$

In 1993, the second recurrent group at $\alpha=0.70$ contained 3 dinoflagellates and a coccolithophore; a second coccolithophore was associated (Table 5). There were no cross-group affinities between groups I and II, even at lower affinity levels. The distribution of group II was a mirror image of the distribution of group I (Fig. 7B). Group II species were absent from the northern inshore area, and occupied a broad offshore band approaching the coast along the southern lines. Although group II species defined the offshore region, they were not numerically dominant offshore, at least during this sampling period. The most abundant species in the offshore recurrent group. Oxytoxum variabile, ranked 10 th among the offshore species (Table 2). No group emerged which was specific for the southeastern region. However, the abundances of groups I and II both diminished here.

Of the 9 members and associates of the northern inshore group in 1993, 6 were members or associates of the analogous group in 1995 (Table 5). As in 1993, the total abundance of the 4 group I species averaged $20 \%$ of the total phytoplankton and was correlated with the $10 \mathrm{~m}$ chlorophyll $(\rho=0.73, p<0.001)$. As in 1993, maximum abundances of the first group occurred at the northern inshore stations (Fig 8A), and some species were present at every station except 2 along line 93. Species were transported offshore along line 90 , presumably by the meander and eddy seen in the maps of dynamic height and $10 \mathrm{~m}$ chlorophyll. A local maximum at Stn 90.90 was due to an increase in the abundance of Emiliania huxleyi, and the role of hydrography, although implicated, is difficult to identify. 
Table 4. Distribution of similar and dissimilar $(p<0.01)$ and neutral $(p>0.01)$ relationships within and between station groups (inshore, offshore, and southeastern, SE) of different years (1993 vs 1995). Values are the observed frequencies (Obs.) and those expected under the null hypothesis of random distribution of relationships (Exp.). Values within parentheses were recalculated from the frequencies of negative and neutral relationships only. The $\chi^{2}$ statistic was calculated from expected values in parentheses

\begin{tabular}{|c|c|c|c|c|c|c|}
\hline \multirow[t]{2}{*}{ Comparison } & \multicolumn{2}{|c|}{ Similar } & \multicolumn{2}{|c|}{ Dissimilar } & \multicolumn{2}{|c|}{ Neutral } \\
\hline & Obs. & Exp. & Obs. & Exp. & Obs. & Exp. \\
\hline Inshore-inshore & 40 & 11.9 & 31 & $137.8(130.6)$ & 481 & $402.3(381.4)$ \\
\hline Offshore-offshore & 14 & 11.9 & 41 & $137.5(137.0)$ & 496 & $402.6(400.0)$ \\
\hline Inshore-offshore & 0 & 24.5 & 512 & $282.8\{289.0\}$ & 621 & $825.7\{844.0\}$ \\
\hline Inshore-SE & 0 & 3 & 29 & $34.4(35.2)$ & 109 & $100.6(102.8)$ \\
\hline Offshore-SE & 1 & 3.8 & $\begin{array}{l}23 \\
\chi^{2}=\end{array}$ & $\begin{array}{r}43.4(44.1) \\
438.2\end{array}$ & $\begin{array}{l}150 \\
(p<\end{array}$ & $\begin{array}{l}126.8\{128.9\} \\
.002\}\end{array}$ \\
\hline
\end{tabular}

inshore area, presumably in response to recent shoaling of nutrient-rich water in this region. In 1993 the offshore region was occupied by a cohesive flora. In 1995, similar species were present offshore, but their dominance structure was less stable. An offshore flora analogous to that in 1993 was only revealed when the criteria for station similarity or species affinity were relaxed. The southeastern stations were within the complicated Ensenada Frontal region. They may receive flora from both the north and the offshore regions and may also receive inputs from the south as well as local

The offshore flora in 1995 was less well organized than in 1993, consistent with the results of the station similarity analyses. No offshore group appeared at $\alpha=0.70$. However, at $\alpha=0.60$, a group analogous to the 1993 offshore group was formed (Table 5). Its spatial distribution was similar (Fig. 8B); the component species were absent from the northern inshore stations where the species of group I reached maximum abundances. However, the total abundance of the group II species was less uniform in the offshore area than in 1993, being greatest at the northwestern stations. As in 1993, the species defining the offshore region were not the dominant species there.

There was no group in 1995 that was clearly related to the red tide earlier in the year. Gonyaulax polyedra formed a 2 species group at $\alpha=0.60$ with the nonphotosynthetic dinoflagellate, Peridinium cf. steinii. There were no associated species. Noctiluca scintillans, which appeared to be closely associated with the decline of the red tide in the La Jolla area (Hayward et al. 1995), did not appear in a group or as an associate.

\section{DISCUSSION}

Two independent analyses were applied to these phytoplankton data One grouped stations with similar floras, and the other grouped species with similar patterns of distribution. These procedures are mathematically unrelated. Thus, consistency of results was not assured, but, having occurred, it strengthened the conclusions.

In both 1993 and 1995 there was a distinct flora occupying the northern influences such as the 1995 red tide. With the present data set, the nature of the flora in the southeast region must remain speculative. It does, however, appear risky to generalize directly from events in the southeast region (including the SIO pier) to the rest of the CalCOFI area.

The boundary between the northern inshore region and the offshore region was influenced by the nearsurface circulation patterns. This influence could be seen in the inshore flora of the offshore eddy at Stn 87.70 in 1993, the inshore flora of the offshore meander at Stn 80.70 in 1995 and the incursion of offshore flora onshore in the south in both years. Processes associated with the California Current jet have been shown to redistribute nutrients and biomass offshore (Sver-

Table 5. Composition of recurrent groups

\begin{tabular}{|ll|}
\hline 1993 & 1995 \\
\hline Group I: inshore species $(\alpha=0.70)$ & Group I: inshore species $(\alpha=0.70)$ \\
Chaetoceros debilis & Chaetoceros debilis \\
Skeletonema costatum & Skeletonema costatum \\
Pseudo-nitzschia spp. (delicate forms) & Pseudo-nitzschia spp. (delicate forms) \\
Chaetoceros radicans & Emiliania huxleyi \\
'Epiphytic cylinder' & \\
Chaetoceros didymus & \\
Associates & Associates \\
Pseudo-nitzschia spp. (robust forms) & Chaetoceros socialis \\
Cylindrotheca closterium & Chaetoceros radicans \\
Thalassionema nitzschioides & 'Epiphytic cylinder' \\
& Pseudo-nitzschia (robust forms) \\
& Leptocylindrus cf. danicus \\
Group Il: Offshore species $(\alpha=0.70)$ & Group II: offshore species ( $\alpha=0.60^{\text {d) }}$ \\
Oxytoxum variabile & Oxytoxum variabile \\
Glenodinium spp. & Glenodinium spp. \\
Syracosphaera pulchra & Dictyocha fibula \\
Torodinium spp. & Associates \\
Associates & Fragilariopsis pseudonana \\
Helicosphaera carteri & Nitzschia cf. bicapitata (small form) \\
& 'No group formed at $\alpha=0.70$ \\
&
\end{tabular}



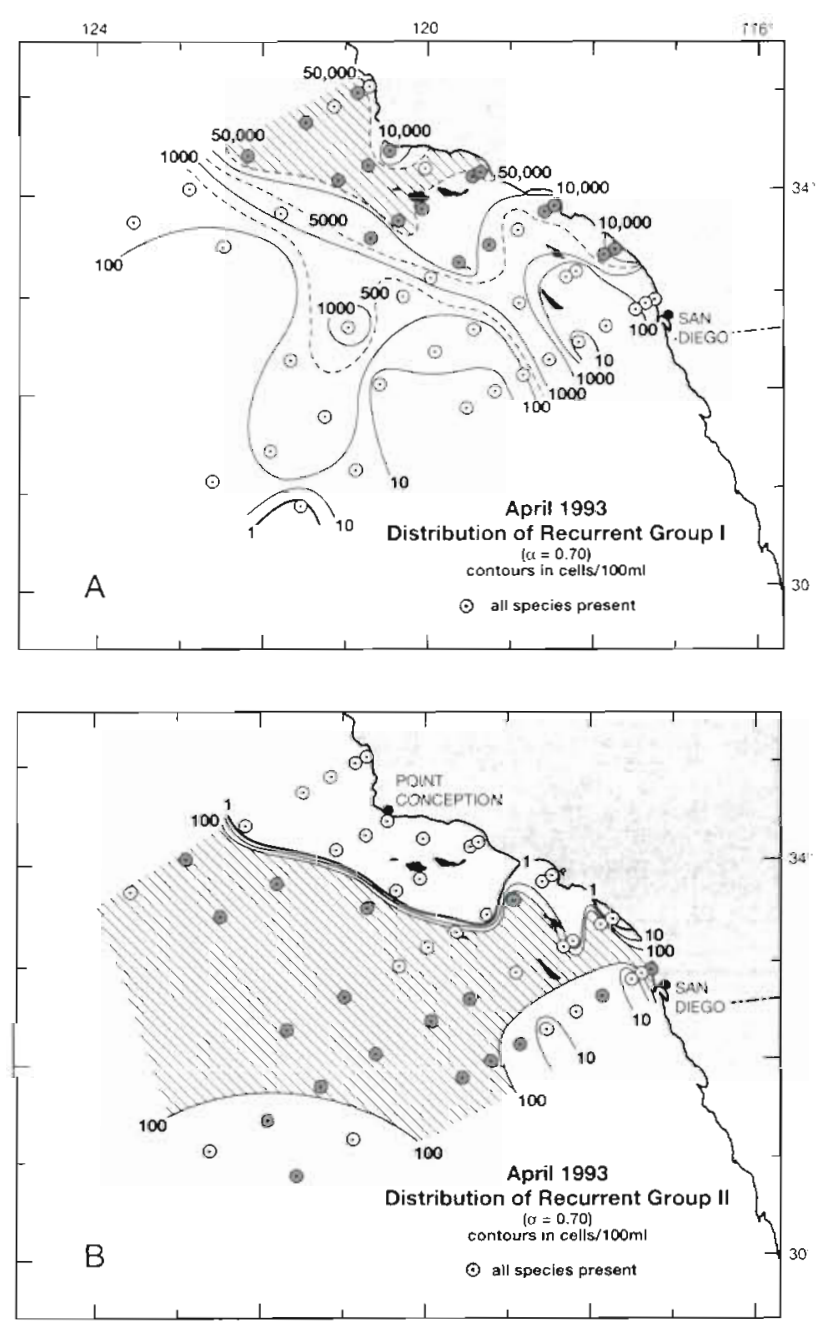

Fig. 7. Distribution of species in recurrent groups, April 1993 (A) Recurrent group I, $\alpha=0.70$. Shading indicates abundances greater than 50000 cells per $100 \mathrm{ml}$. (B) Recurrent. group II, $\alpha=0.70$. Shading indicates abundances greater than 100 cells per $100 \mathrm{ml}$

drup \& Allen 1939, Hayward \& Mantyla 1990, Hood et al. 1990, 1991, Chavez et al. 1991, Strub et al. 1991). However, quantitative demonstration of the dissemination of species as well as biomass is rare.

The most obvious difference between 1993 and 1995 was the less cohesive offshore flora in 1995. There were similar numbers of species present offshore in 1995 and 1993 (203 and 208, respectively, out of a combined species list of 276; Tables $2 \& 3$ ). The mean abundance per station was lower in 1995 than in 1993 (2200 and 4000 cells per $100 \mathrm{ml}$, respectively). Two aspects of species' spatial distribution-greater heterogeneity and greater evenness - may have lessened the stability of the rank order of abundance in 1995. The mean coefficient of variation of species at the offshore

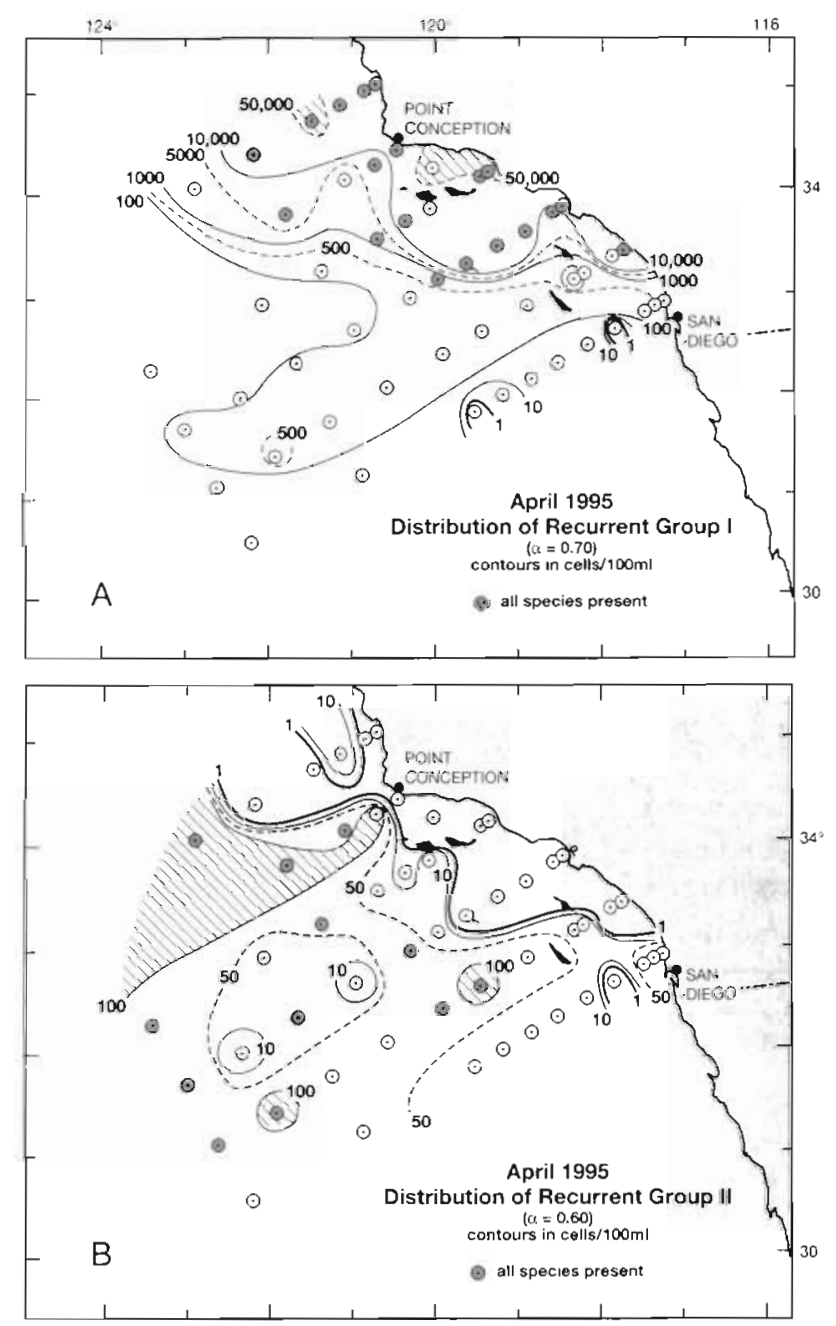

Fig. 8. Distribution of species in recurrent groups, April 1995. (A) Recurrent group I, $\alpha=0.70$. Shading indicates abundances greater than 50000 cells per $100 \mathrm{ml}$. (B) Recurrent group II, $\alpha=0.60$. Shading indicates abundances greater than 100 cells per $100 \mathrm{ml}$

stations was 3.42 in 1995, compared with 2.92 in 1993. For the 24 dominant species (those among the 20 offshore dominants during one or both years), the difference in spatial heterogeneity was significant (signed rank test on the coefficient of variation; $p<0.005$ ). The mean species evenness at offshore stations was significantly greater in 1995 than in 1993 (0.670 and 0.545, respectively; Mann Whitney $U$-test, $p<0.001$ ). The ecological factors leading to greater evenness and greater heterogeneity in 1995 remain unknown. In addition, the offshore flora may have been partially overshadowed by other species in 1995, especially residuals from the red tide seen earlier in the year.

Hayward \& Venrick (in press) have defined 4 regions in the California Current on the basis of the magnitude 
and scales of physical and chemical variability and the 12-yr temporal patterns of chlorophyll (Fig. 9). They defined a northern coastal region, a southern coastal region, and an offshore region. These 3 areas correspond with the areas defined here on the basis of floristics. The chlorophyll data showed unique seasonal cycles in the northern inshore and offshore regions, with an intermediate cycle in the southeast (Fig. 9). This is consistent with the floristic evidence of marked differences between the offshore and northern inshore regions with confluence in the southeastern region. The fourth region of Hayward \& Venrick was a band between northern coastal and offshore regions, within which stations had few or no affinities. The authors hypothesized that this region represents hydrographically mediated fluctuations in the position of the boundary between inshore and offshore regimes. The present floristic analysis supports this interpretation; although distorted by current flow, the boundary between inshore and offshore flora was sharp. Most of the stations influenced by current flow (e.g. Stns 87.70 in 1993 and 80.70 in 1995) were located within the boundary region of Hayward \& Venrick.

Recurrent group analysis defined small groups of species that characterized the flora of the offshore and northern inshore groups of stations. The northern inshore species are members of a relatively restricted group of temperate to subarctic species that respond to enrichment (Verity \& Smetacek 1996). Some or all of the diatoms have been reported from environments as diverse as the spring blooms of Gulf of Maine (USA) and the Norwegian fjords, and upwelling regions in the Gulf of Panama (e.g. Smayda 1980). Emiliania huxleyi is a ubiquitous bloom former (e.g. Smayda 1980, Balch et al. 1991). In short, there is nothing unique about the spring flora in the CalCOFI region. The fact that other species in this restricted group (e.g. Asterionella japonica or several species in the genus Thalassiosira) were not abundant in this study may be more an artifact of sample timing than of phytogeography

Except for Fragilariopsis pseudonana, species in the offshore recurrent groups are all common in the Central North Pacific environment (Venrick 1982). The 2 dinoflagellates, Oxytoxum variabile and Glenodinium spp., have been used as indicator species for the shallow flora in the Central Pacific (Venrick 1988).

These analyses of phytoplankton species reveal regional differences that are not apparent from maps of chlorophyll. The inshore-offshore decrease in phytoplankton biomass was accompanied by a shift in species composition in which an increasing number of dinoflagellates, coccolithophores and other flagellate species became dominant, replacing the diatoms of the inshore region. This transition was rapid, and repre-
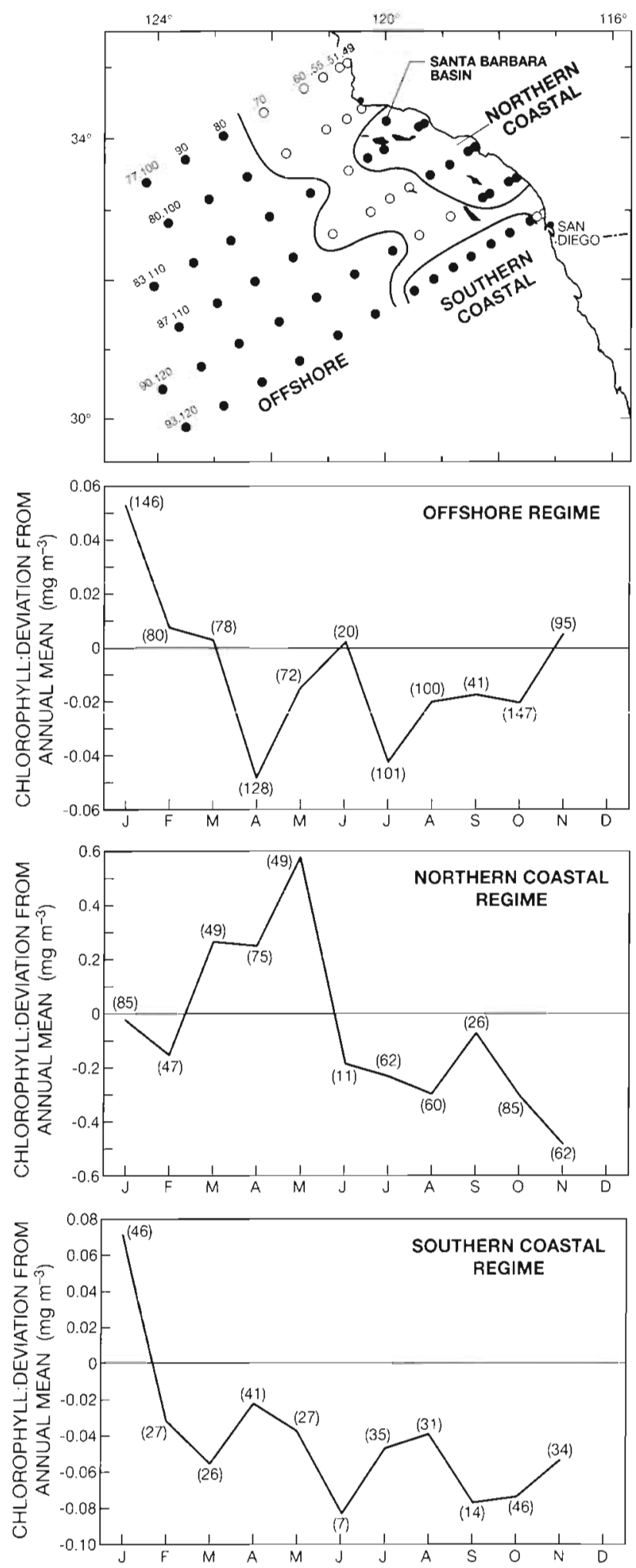

Fig. 9. Location of environmental regimes based upon the 12 -yr patterns of near-surface chlorophyll and the seasonal cycles of chlorophyll within each regime (modified from Hayward \& Venrick in press). Numbers in parentheses are the numbers of samples averaged for each monthly deviation 
sents an important difference in food quality for herbivorous zooplankton. It was almost certainly accompanied by an increased importance of the microbial loop and restructuring of the food web as conditions became increasingly stratified and oligotrophic. Nevertheless, although the inshore-offshore boundary was abrupt, it was not absolute. The northern inshore species were found throughout the near-surface layer of the CalCOFI region and, at offshore stations, they were often more abundant than the species in the offshore recurrent groups. The environmental characteristics of the offshore stations are similar to those of the Central Pacific environment (Hayward \& Venrick in press). Nevertheless, these stations experience periodic inputs of species and biomass from the CalCOFI upwelling centers that are not experienced farther offshore. Observations from the outer portion of the CalCOFI area may not always represent the Central Pacific

The previous studies most comparable to the data presented here are based upon data compiled by W. E Allen from a series of cruises in the southern California Current between 1938 and 1941 (Sverdrup \& Allen 1939, Allen 1945a, b, Sargent \& Walker 1948). Data on the total abundance of diatoms are available in cruise reports (Sverdrup et al. 1942, 1944, 1947). Species composition is summarized in journal articles (Allen 1945a, b, Sargent \& Walker 1948), but, unfortunately, the original data by species have not been published.

The summary of the phytoplankton from these cruises (Allen 1945a) is remarkable for the number of preliminary observations that have since become corner-stones of phytoplankton ecology. There is the report of the 'vernal exuberance (seasonal biological rhythm...) in activity of planktonic diatoms', the idea that 'organisms tend to distribution as clouds in air', and the 'astonishing' finding 'that the recorded extremes of productiveness were characteristic of only two or four species belonging to two genera, that is Chaetoceros and Nitzschia.' Subsequent analysis of the 1938 data established the relation between high numbers of diatoms and 'new' (recently upwelled) water and the importance of the flow pattern in transporting both through the region (Sverdrup \& Allen 1939).

In 1940 there were cruises twice a month through the spring. These covered roughly $50 \%$ of the present CalCOFI area. Because of recent interest in long-term. environmental changes, it is useful to compare Allen's diatom data with those from the recent cruises, in spite of the procedural differences. I have assumed that the $10 \mathrm{~m}$ counts of Allen are most comparable to my mixed-layer samples, and I have calculated from my data the total number of diatoms in the region surveyed by Allen.
The distribution of diatoms from Allen's April data (Fig. 10) showed 2 stages in the development of the spring bloom. Diatoms from the later period had higher abundances over a broader area, following the cold flow of the California Current. Populations on the following cruises, 10 to 21 May and 27 May to 7 June 1940 , were greatly reduced. Thus, the samples from 22 April to 3 May appear to have been the closest to the peak of the 1940 spring bloom.

Within the restrictions imposed by the different procedures, the agreement between the 1940 data and those of 1993 and 1995 is good. The overall maximum concentration of diatoms (nearly 5000 diatoms $\mathrm{ml}^{-1}$ ) was recorded on 12 April 1995 at CalCOFI Stn 90.30. The second highest abundances (over 2000 diatoms $\mathrm{ml}^{-1}$ ) were recorded by Allen along his northern line on 30 April and 1 May 1940 (Fig. 10). Concentrations of total diatoms in 1993 and 1995 are comparable to those of 1940 , but, without knowing the loss of diatoms from Allen's samples or the timing of the 2 sets of samples relative to the spring cycle, we cannot compare the relative strengths of the spring blooms.

The species which Allen mentioned (Allen 1945b) agree with the abundant species in the present study: Chaetoceros compressus, C. debilis, C. radicans, C. costatus and Nitzschia seriata lincluding Pseudo-nitzschia australis and $P$. pungens $\mathrm{f}$. multiseries (Lange et al. 1994), both included in my category of robust Pseudonitzschia]. A discrepancy was the absence from Allen's list of Skeletonema costatum (ranked 2 and 3 in 1993 and 1995). However, Allen reported $S$. costatum to be present in 'good' abundances the following May, substantiating the presence of this species and its potential retention in Allen's samples.

The centers of abundances of the more recent populations extended closer to the coast. Hydrographic data from 22 April to 3 May 1940 showed near-surface water warmer than $16^{\circ} \mathrm{C}$ throughout the entire Southern California Bight. This, in turn, was related to a well-developed Southern California eddy (Allen 1945b), more typical of winter than spring flow patterns (Hayward et al. 1994). This is one more example of the influence of hydrography on the distribution of phytoplankton, but an explanation for the unusual spring hydrographic pattern in 1940 is not available.

In the past 50 yr there have been advances in computers and analytical techniques have allowed more objective syntheses of greater numbers of phytoplankton species. In the present study, these have facilitated the definition of an offshore flora, characterized primarily by flagellates, in addition to a diatom-dominated inshore flora. They have allowed a more quantitative description of the hydrographic redistribution of these flora. Nevertheless, given the $50+$ yr separating the 2 sets of data, the similarities are more impressive than the differences. 


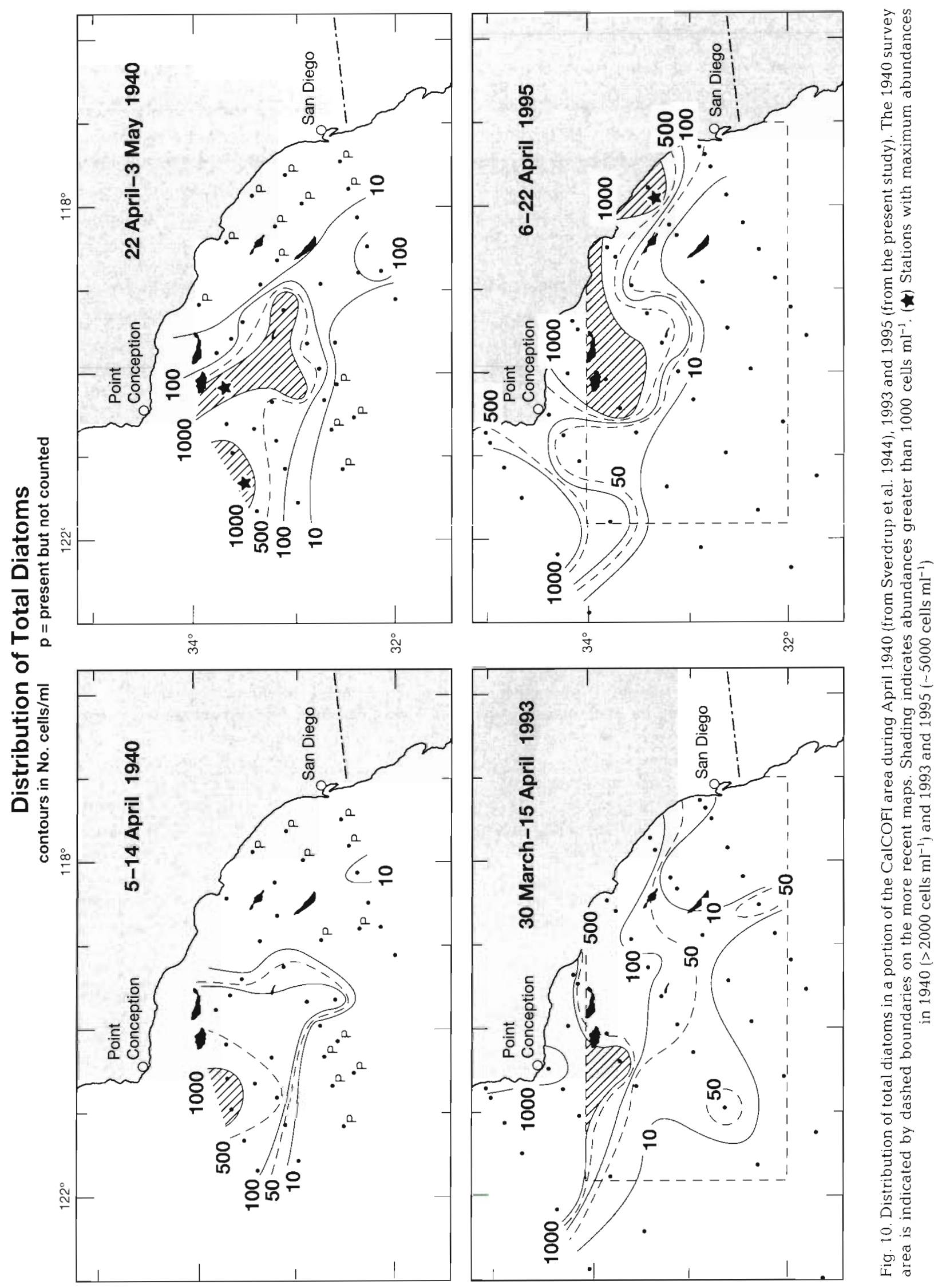


Appendix 1. Taxonomic nomenclature and note for species noted in text. Where possible, taxonomy follows Tomas (1997)

\begin{tabular}{|c|c|}
\hline $\begin{array}{l}\text { Diatoms } \\
\text { Chaetoceros compressus } \\
\text { Chaetoceros costatus } \\
\text { Chaetoceros debilis } \\
\text { Chaetoceros didymus } \\
\text { Chaetoceros radicans } \\
\text { Chaetoceros socialis } \\
\text { Chaetoceros cf. vanheurcki } \\
\text { Leptocylindrus cf. danicus } \\
\text { Skeletonema costatum } \\
\text { Cylindrotheca closterium } \\
\text { 'Epiphytic cylinder' } \\
\text { Fragilariopsis pseudonana } \\
\text { Haslea wawrikae } \\
\text { Nitzschia bicapitata (small form) } \\
\text { Nitzschia cf. longissima } \\
\text { Mastogloia woodiana } \\
\text { Pseudo-nitzschia spp. (delicate forms) } \\
\text { Pseudo-nitzschia spp. (robust forms) } \\
\text { Thalassionema nitzschioides }\end{array}$ & $\begin{array}{l}\text { Lauder } \\
\text { Pavillard } \\
\text { Cleve } \\
\text { Ehrenberg } \\
\text { Schutt } \\
\text { Lauder } \\
\text { Gran; includes C. Constrictus Gran } \\
\text { Cleve; may include L. minimus (Gran) } \\
\text { (Greville) Cleve } \\
\text { (Ehrenberg) Lewin and Reimann } \\
\text { Small pennate often epiphytic on detritus } \\
\text { Hasle (Hasle) } \\
\text { (Hustedt) Simonsen } \\
\text { May be conspecific with } N \text {. bicapitata Cleve } \\
\text { (Brebisson) Ralfs } \\
\text { Taylor } \\
\text { Probably several species } \\
\text { Includes P. australis Frenguelli and P. multiseries (Hasle) Hasle } \\
\text { (Grunow) Mereschkowsky }\end{array}$ \\
\hline $\begin{array}{l}\text { Dinoflagellates } \\
\text { Glenodinium spp. } \\
\text { Gonyaulax polyedra } \\
\text { Gymnodinium sanguineum } \\
\text { Noctiluca Scintillans } \\
\text { Oxytoxum variabile } \\
\text { Peridinium cf. steinii } \\
\text { Torodinium spp. }\end{array}$ & $\begin{array}{l}\text { May include } 2 \text { or } 3 \text { species of different genera } \\
\text { Now Lingulodinium polyedrum (Stein) Dodge } \\
\text { Hirasaka; formerly G. splendens } \\
\text { (Macartney) Kofoid and Swezy; formerly N. miliaris } \\
\text { Schiller } \\
\text { Jorgensen; may have been transferred to Protoperidinium }\end{array}$ \\
\hline $\begin{array}{l}\text { Coccolithophores } \\
\text { Emiliania huxleyi } \\
\text { Gephyrocapsa ornata } \\
\text { Gephyrocapsa spp. } \\
\text { Heliosphaera carteri } \\
\text { Syracosphaera pulchra }\end{array}$ & $\begin{array}{l}\text { (Lohmann) Hay \& Mohler } \\
\text { Heimdah! } \\
\text { Includes G. ericsonii McIntyre \& Be and possibly others } \\
\text { (Wallich) Kamptner } \\
\text { Lohmann }\end{array}$ \\
\hline $\begin{array}{l}\text { Others } \\
\text { Dictyocha fibula } \\
\text { Leucocryptos marina } \\
\text { Phaeocystis pouchetii }\end{array}$ & $\begin{array}{l}\text { Ehrenberg; silicoflagellate } \\
\text { (Braarud) Butcher; nonphotosynthetic chromophyte } \\
\text { (Hariot) Lagerheim; prymnesiophyte (only the colonial form counted) }\end{array}$ \\
\hline
\end{tabular}

Acknowledgements. This work was supported by the Marine Life Research Group of Scripps Institution of Oceanography, which is the SIO affiliate of the CalCOFI Program. I am especially grateful to the CalCOFI technicians and volunteers who collected these samples and remembered not to double rinse the formalin from the sample bottles.

\section{LITERATURE CITED}

Abbott MR, Zion PM (1987) Spatial and temporal variability of plankton pigment off Northern California during Coastal Ocean Dynamics Experiment 1. J Geophys Res 92 $1745-1755$

Allen WE (1936) Occurrence of marine plankton diatoms in a ten-year series of daily catches in Southern California. Am J Bot 23:60-63

Allen WE (1939) Summary of results of twenty years of researches on marine phytoplankton. Proc 6th Pacif Sci Congr 3:577-583

Allen WE (1941) Twenty years' statistical studies of marine plankton dinoflagellates of Southern California. Am Midl Nat 26:603-635

Allen WE (1945a) Seasonal occurrence of marine plankton diatoms off southern California in 1938. Bull SIO 5: 293-334
Allen WE (1945b) Vernal distribution of marine plankton diatoms offshore in southern California in 1940. Bull SIO 5:335-369

Balch WM, Holligan PM, Ackleson SG, Voss KJ (1991) Biological and optical properties of mesoscale coccolithophore blooms in the Gulf of Maine. Limnol Oceanogr 36: 629-643

Barber RT, Smith RL (1981) Coastal upwelling systems. In: Longhurst AR (ed) Analysis of marine ecosystems. Academic Press, New York, p 31-68

Bernal PA (1979) Large-scale biolagical events in the California Current. CalCOFI Rep 20:89-101

Chavez FP, Barber RT, Kosro PM, Huyer A, Ramp SR, Stanton TP, de Mendiola BR (1991) Horizontal transport and the distribution of nutrients in the coastal transition zone off northern California: effects on primary production, phytoplankton biomass and species composition. J Geophys Res 96:14833-14848

Colebrook JM (1977) Annual fluctuations in biomass of taxonomic groups of zooplankton in the California Current, 1955-59. Fish Bull 75:357-368

Conover WJ (1971) Practical nonparametric statistics. John Wiley and Sons, New York

Eppley RW (1986) Plankton dynamics of the Southern California Bight. Springer-Verlag, New York

Fager EW (1957) Determination and analysis of recurrent 
groups. Ecology 38:586-595

Fager EW, McGowan JA (1963) Zooplankton species groups in the North Pacific. Science 140:144-151

Goodman D, Eppley RW, Reid FMH (1984) Summer phytoplankton assemblages and their environmental correlates in the Southern California Bight. J Mar Res 42:1019-1049

Hayward TL, Cayan DR, Franks PJS, Lynn RJ, Mantyla AW, McGowan JA, Smith PE, Schwing FB, Venrick EL (1995) The state of the California Current in 1994-1995: a period of transition. CalCOFI Rep 36:19-39

Hayward TL, Cummings SL, Cayan DR, Chavez FP, Lynn RJ, Mantyla AW, Niiler PP, Schwing FB, Veit RR, Venrick EL (1996) The state of the California Current in 1995-1996: continuing declines in macrozooplankton biomass during a period of nearly normal circulation. CalCOFI Rep 37:22-37

Hayward TL, Mantyla AW (1990) Physical, chemical and biological structure of a coastal eddy near Cape Mendocino. J Mar Res 48:825-850

Hayward TL, Mantyla AW, Lynn RJ, Smith PE, Chereskin TK (1994) The state of the California Current in 1993-1994 CalCOFI Rep 35:19-35

Hayward TL, Venrick EL (in press) Nearsurface pattern in the Calitornia Current: coupling between physical and biological structure. Deep Sea Res

Hood RR, Abbott MR, Huyer A (1991) Phytoplankton and photosynthetic light response in the coastal transition zone off northern California in June 1987. J Geophys Res 96: $14769-14780$

Hood RR, Abbott MR, Huyer A, Kosro PM (1990) Surface patterns in temperature, flow, phytoplankton biomass, and species composition in the coastal transition zone off Northern California. J Geophys Res 95:18081-18094

Jones BH, Brink KH, Dugdale RC, Stuart DW, Ven Leer JC, Blasco D, Kelley JC (1983) Observations of a persistent up. welling center off Point Conception, California. In: Suess E, Thiede J (eds) Coastal upwelling, its sediment record. Part A: Responses of the sedimentary regime to present coastal upwelling. Plenum Press, New York, p 37-60

Lange CB. Reid FMH, Vernet M (1994) Temporal distribution of the potentially toxic diatom Pseudonitzschia australis at a coastal site in Southern California. Mar Ecol Prog Ser 104:309-312

Legendre L, Legendre P (1983) Numerical ecology. Developments in environmental modeling 3. Elsevier Scientific Publishing Co, New York

Manly BFJ (1991) Randomization and Monte Carlo methods in biology. Chapman and Hall, London

Pelaez J, McGowan JA (1986) Phytoplankton pigment patterns in the California Current as determined by satellite. Limnol Oceanogr 31:927-950

Sargent MC. Walker TJ (1948) Diatom populations associated with eddies off southern California in 1941. J Mar Res 7 490-505

Editorial responsibility: Otto Kinne (Editor), Oldendorf/Luhe, Germany
SIO (Scripps Institution of Oceanography) (1993) Physical. chemical and biological data. CalCOFI cruise 9301, 12-27 January 1993 and CalCOFl cruise 9304, 30 March-15 April 1993. SIO Ref $93-26$

SIO (Scripps Institution of Oceanography) (1995) Physical, chemical and biological data. CalCOFI cruise 9501, 4-21 January 1995 and CalCOFI cruise 9504, 6-22 April 1995. SIO Ref $95-33$

Smayda TS (1980) Phytoplankton species succession. In Morris I (ed) The physiological ecology of phytoplankton. Univ Calif Press, Berkeley, p 493-570

Strub PT, Kosro MP, Huyer A and the CTZ Collaborators (1991) The nature of cold filaments in the California Current System. J Geophys Res 96:14743-14768

Sugihara G, May RM (1990) Nonlinear forecasting as a way of distinguishing chaos from measurement error in time series. Nature 344:734-741.

Sverdrup HU, Allen WE (1939) Distribution of diatoms in relation to the character of water masses and currents off southern California in 1938. J Mar Res 2:131-144

Sverdrup HU, Fleming RH, Miller LH, ZoBell CE (1942) Oceanographic observations on the 'E.W. Scripps' cruises of 1938. Rec Observ Scripps Inst Oceanogr 1:1-64

Sverdrup HU, Fleming RH, ZoBell CE (1944) Oceanographic observations on the 'E.W. Scripps' cruises of 1940. Rec Observ Scripps Inst Oceanogr 1:161-248

Sverdrup HU, Fleming RH, ZoBell CE (1947) Oceanographic observations on the 'E.W. Scripps' cruises of 1941 Rec Observ Scripps Inst Oceanogr 1:249-408

Tangen K (1978) Nets. In: Sournia A (ed) Phytoplankton manual. Monogr Oceanogr Meth 6, UNESCO, Paris, p 50-58

Thomas AC, Strub PT (1990) Seasonal and interannual variability of pigment concentrations across a California Current frontal zone. J Geophys Res 95:13023-13042

Tomas CR (1997) Identifying marine phytoplankton. Academic Press, San Diego

Tont SA (1976) Short-period climatic fluctuations: effects on diatom biomass. Science 194:942-944

Tont SA (1981) Temporal variability in diatom abundance off Southern California in relation to surface temperature, air temperature and sea level. J Mar Res 39:191-201

Tont SA (1987) Variability of diatom species populations: from days to years. J Mar Res 45:985-1006

Venrick EL (1982) Phytoplankton in an oligotrophic ocean: observations and questions. Ecol Monogr 52:129-154

Venrick EL (1988) The vertical distributions of chlorophyll and phytoplankton species in the North Pacific central environment. J Plankton Res 10:987-998

Verity PG. Smetacek V (1996) Organism life cycles, predation, and the structure of marine pelagic ecosystems. Mar Ecol Prog Ser 130:277-293

Zar JH (1984) Biostatistical analysis. Prentice-Hall, Englewood Cliffs, NJ

Submitted: December 11, 1997; Accepted: March 20, 1998 Proofs received from author(s): May 26, 1998 